\title{
Combination ACE inhibitor and angiotensin receptor blocker therapy was better than monotherapy in non-diabetic renal disease
}

\author{
Nakao N, Yoshimura A, Morita H, et al. Combination treatment of angiotensin-II receptor blocker and \\ angiotensin-converting-enzyme inhibitor in non-diabetic renal disease (COOPERATE): a randomised controlled trial. \\ Lancet 2003;361:117-24.
}

QUESTION: In patients with non-diabetic renal disease, what is the effectiveness of the angiotensin II receptor blocker (ARB) losartan, the angiotensin converting enzyme (ACE) inhibitor trandolapril, or the 2 drugs combined for delaying disease progression?

\section{Design}

Randomised (unclear allocation concealment*), blinded (clinicians, patients, data collectors, and monitoring committee),* controlled trial with 3 years of follow up.

\section{Setting}

Hospital outpatient renal clinic serving 3 cities in Japan.

\section{Patients}

301 patients 18-70 years of age who had chronic non-diabetic renal insufficiency, persistent proteinuria, and no history of allergic reaction to drugs. Exclusion criteria included immediate need for renal replacement therapy; need for corticosteroids, non-steroidal antiinflammatory drugs, or immunosuppressive drugs; proteinuria $>10 \mathrm{~g} /$ day and hypoalbuminaemia $<28 \mathrm{~g} /$; other serious disease; and pregnancy or breastfeeding. 263 patients (mean age 45 y, 54\% men) completed an 18 week run in period and were randomised. Follow up of these patients was $97 \%$.

\section{Intervention}

Patients were allocated to losartan, $100 \mathrm{mg} /$ day plus placebo $(\mathrm{n}=89)$; trandolapril, $3 \mathrm{mg} /$ day, plus placebo $(\mathrm{n}=86)$; or a combination of losartan, $100 \mathrm{mg}$, and trandolapril, $3 \mathrm{mg} /$ day $(\mathrm{n}=88)$.

\section{Main outcome measures}

A combined endpoint of time to doubling of serum creatinine concentration or end stage renal disease (ESRD) (glomerular filtration rate $<7 \mathrm{ml} / \mathrm{min}$ per $1.73 \mathrm{~m}^{2}$ or implementation of dialysis). Secondary outcomes were changes in blood pressure and urinary protein excretion, and adverse effects.

\section{Main results}

Analysis was by intention to treat. At 3 years, fewer patients who received combination treatment reached the combined endpoint than did patients who received either drug with placebo (table). Blood pressure did not differ between groups. Patients in the combination treatment group had the greatest decrease in urinary protein excretion rate (maximum decrease $75 \%$ ) compared with losartan alone (42\%) and trandolapril alone (44\%). Groups did not differ for adverse effects, and no patient had an acute decline in renal function.

\section{Conclusion}

In patients with non-diabetic renal disease, losartan and trandolapril combined were better than either drug alone for delaying disease progression.

*See glossary.

Source of funding: in part, Ministry of Health, Labour, and Welfare,Japan.

For correspondence: Dr N Nakao, Showa University, Yokohama, Japan.

lancetip@yahoo.co.jp

Abstract and commentary also appear in ACP Journal Club.

Combination treatment $v$ losartan or trandolapril alone for non-diabetic renal disease at 3 yearst

\begin{tabular}{cllll} 
Outcome & Comparison & Event rates & RRR (95\% Cl) & NNT (Cl) \\
$\begin{array}{c}\text { Combined } \\
\text { endpoint }\end{array}$ & $\begin{array}{l}\text { Combination } \\
\text { treatment } v \text { losartan }\end{array}$ & $11 \% v 23 \%$ & $49 \%(0.5$ to 75$)$ & $9(5$ to 1722$)$ \\
\hline & $\begin{array}{l}\text { Combination } \\
\text { treatment } v \text { trandolapril }\end{array}$ & $11 \% v 23 \%$ & $50 \%(1.7$ to 75$)$ & $9(5$ to 359$)$ \\
\hline
\end{tabular}

†Combined endpoint $=$ time to doubling of serum creatinine concentration or end stage renal disease. Abbreviations defined in glossary; RRR, NNT, and $\mathrm{Cl}$ calculated from data in article.

\section{COMMENTARY}

ACE inhibitors are standard treatment for slowing the progression of non-diabetic renal disease and this benefit is mediated by factors in addition to lowering blood pressure and urinary protein excretion. ${ }^{1}$ The possibility that additional reductions in the rate of progression are achievable has led to consideration of the combination of an ACE inhibitor with an ARB. Several small short term studies have shown an improved antiproteinuric effect and the safety of this combination treatment.

The COOPERATE study confirms these findings and reports a remarkable reduction of the long term combined outcome of doubling of serum creatinine or ESRD with combination treatment compared with either drug alone. Only 1 of 85 patients in the combination treatment group reached ESRD at 3 years. These results were achieved with excellent blood pressure control (125/72 $\mathrm{mm} \mathrm{Hg}$ during the trial), marked dietary protein restriction, and the use of maximum doses of both classes of drugs.

Previous studies of ACE inhibitors ${ }^{2-3}$ were designed to achieve diastolic blood pressures $<90 \mathrm{~mm} \mathrm{Hg}$ with submaximal doses and showed less compliance with low protein diets than did the COOPERATE trial. The generalisability of this study is hampered by the relatively young age of the patients (mean age $45 \mathrm{y}$ ) and the preponderance of glomerular renal disease, primarily IgA nephropathy, an uncommon cause of ESRD in Europe and North America. Future studies evaluating combination treatment need to include older patients with underlying nephrosclerosis before this promising approach can be recommended as a safe and effective therapy for non-diabetic renal disease.

Wolfgang J Weise, MD University of Vermont Burlington, Vermont, USA

1 Jafar TH, Schmid CH, Landa M, et al. Angiotensin-converting enzyme inhibitors and proression of nondiabetic renal disease. A meta-analysis of patient-level data. Ann Intern Med 2001;135:73-87. Ruggenenti P, Perna A, Gherardi G, et al. Renoprotective properties of ACE-inhibition non-diabetic nephropathies with non-nephrotic proteinuria. Lancet 1999;354:359-64.

3 Maschio G, Alberti D, Janin G, et al. Effect of the angiotensin-converting-enzyme inhibitor benazepril on the progression of chronic renal insufficiency. The AngiotensinMed 1996;334:939-45. 